A $C \underset{\text { publications }}{\mathrm{C}}$ Rec. Nat. Prod. 15:6(2021) 513-528

records of natural

products

\title{
Anticholinergic, Antidiabetic and Antioxidant Activities of Ferula orientalis L. Determination of Its Polyphenol Contents by LC-HRMS
}

\author{
Hatice Kızıltaş ${ }^{1}$ ', Ahmet C. Gören ${ }^{2,3 *}$, Zeynebe Bingöl ${ }^{4}{ }^{4,5}$, \\ Saleh H. Alwasel $\oplus^{6}$ and İlhami Gülçin $\odot$ 5,* \\ ${ }^{1}$ Vocational School of Health Services, Van Yuzuncu Yil University, 65080-Van, Türkiye \\ ${ }^{2}$ Department of Analytical Chemistry, Faculty of Pharmacy, Bezmialem Vakif University, \\ 34093-Istanbul, Türkiye \\ ${ }^{3}$ Drug Application and Research Center (ILMER), Bezmialem Vakif University, 34093- \\ Istanbul, Türkiye \\ ${ }^{4}$ Vocational School of Health Services, Tokat Gaziosmanpasa University, 65080-Van, Türkiye \\ ${ }^{5}$ Department of Chemistry, Faculty of Sciences, Atatürk University, 25240-Erzurum, Türkiye \\ ${ }^{6}$ Department of Zoology, College of Science, King Saud University, Riyadh, Saudi Arabia
}

(Received February 15, 2021; Revised April 07, 2021; Accepted April 10, 2021)

\begin{abstract}
To evaluate the antioxidant activity of evaporated ethanolic extract of Ferula orientalis L. (EEFO) and lyophilized water extract of Ferula orientalis L. (WEFO) several in vitro antioxidant methods such as ABTS ${ }^{++}$ scavenging activity, DPPH* scavenging activity, $\mathrm{Fe}^{3+}$ reduction method, cupric ions $\left(\mathrm{Cu}^{2+}\right)$ reduction capacity, and metal ion $\left(\mathrm{Fe}^{2+}\right)$-binding activities using ferrozine reagent were separately performed. Also, BHT, $\alpha$-tocopherol and ascorbic acid were used as the standard antioxidant molecules. Moreover, some phenolic compounds that are responsible for antioxidant abilities of EEFO and WEFO were determined by LC-HRMS. EEFO and WEFO demonstrated effective antioxidant abilities when compared with the standards. EEFO demonstrated $\mathrm{IC}_{50}$ values of $1.946 \mu \mathrm{g} / \mathrm{mL}$ against acetylcholinesterase (AChE), $0.815 \mu \mathrm{g} / \mathrm{mL}$ against $\alpha$-glycosidase, and $0.675 \mu \mathrm{g} / \mathrm{mL}$ against $\alpha$-amylase.
\end{abstract}

Keywords: Ferula orientalis; $\alpha$-glycosidase; antioxidant activity; phenolic compound; acetylcholinesterase, $\alpha$ amylase. () 2021 ACG Publications. All rights reserved.

\section{Introduction}

Today, herbs are used as a potential resource to develop new products in the cosmetic, food and pharmaceutical industries [1]. Ferula is a genus of flowering plants in the Apiaceae family, found in the region from Central Asia to the Mediterranean. It grows mostly in arid climates and having approximately 170 species [2]. Ferula orientalis L. is a perennial herb that grows in Central Asia and the Eastern Mediterranean region. It grows on sunny and dry hills, walls, waste soils and limestones and moist soils in the spring. Therefore, this plant can adapt well to the Mediterranean climate and face climatic stresses. It can form large leaf clusters in spring and winter and remaining dormant in mid-

\footnotetext{
*Corresponding author: E-Mail: igulcin@atauni.edu.tr (I Gulcin); Phone:+90-442-231-43-75, Fax:+90-442 2314109 ahmetcgoren@yahoo.com (A.C. Goren)
} 


\section{Anticholinergic, antidiabetic and antioxidant activities of Ferula orientalis}

summer depending on climatic conditions. In addition, this plant can reach length of about $2 \mathrm{~m}$ with numerous yellow flower clusters. It is known that Ferula orientalis was used as aphrodisiac, antispasmodic, stimulant, and expectorant effects [2,3].

Antioxidants are natural or synthetic molecules that inhibit oxidation procedure, which produce free radicals and oxidative stress [4,5]. Antioxidants can preserve the human body from the undesired effects of ROS [6,7]. They had beneficial effects in preventing chronic diseases including cardiovascular diseases, Parkinson's disease, cancer, diabetes, Alzheimer's disease (AD), cataracts and the other chronicle disorders. Also, they can terminate the radical chain reactions and neutralize free radicals, which attack cells or biomolecules [8,9]. Vegetables and fruits are healthy foods and rich sources in terms of a large spectrum of natural antioxidants. In this context most antioxidant molecules obtained from natural sources like plants have been found as ROS or free radical scavengers [10,11]. For this reason, alternative, safer, natural and reliable plant-derived antioxidants are preferred as natural antioxidants $[12,13]$.

Antioxidants delay or avoid the onset of major degenerative diseases including diabetes mellitus (DM) and $\mathrm{AD}$ [13-15]. One of the main targets in the treatment of DM is the $\alpha$-glycosidase, the activity of which is fundamental to the degradation of dietary polysaccharides. $\alpha$-Glycosidase enzyme inhibitors block absorption of monomeric sugar units in the intestinal tract. This limits postprandial plasma glucose level. AGIs can thus be used in the treatment of diabetes and obesity [16,17]. AD is the most typical and common dementia form among elderly people, which negatively affect the personal ability to carry out daily activities. Moreover, it is well known that the loss of cholinergic transmission is one of the major $\mathrm{AD}$ causes. Therefore, acetylcholinesterase inhibitors that enhance cholinergic transmission can be used to treat $\mathrm{AD}$. Among them, tacrine is currently used in the palliative treatment for mild to moderate AD. It is known that most of the drugs used today have undesired side effects including hepatotoxicity and gastrointestinal anomalies such as nausea, diarrhea. $[18,19]$. Especially, it was reported that tacrine had some side effects including vomiting, nausea, stomach upset, weight loss, agitation, diarrhea, shaking, and skin rash [20,21]. Therefore, there is a great demand to develop and use $\alpha$-glycosidase and AChE inhibitors with antioxidant properties. Phenolic compounds also have anti-AD properties and $\alpha$ glycosidase inhibition profile. Therefore, one of the most important approaches for treatment of neurodegenerative diseases and DM is natural compounds and products [19, 22-25].

In this study, we aimed to investigation the $\mathrm{Cu}^{2+}$ reducing (CUPRAC method), $\mathrm{Fe}^{3+}$ reducing and FRAP reducing abilities, DPPH ${ }^{*}, \mathrm{ABTS}^{\cdot+}$ scavenging effects and $\mathrm{Fe}^{2+}$ chelating ability of EEFO and WEFO. An important feature of the study is to quantitatively elucidate some important phenolic contents in the both extracts with LC-HRMS chromatography. Also, another main goal of this study was to determine the possible inhibition effects of EEFO and WEFO against acetylcholinesterase and $\alpha-$ glycosidase enzymes linked to Alzheimer's disease and diabetes.

\section{Materials and Methods}

\subsection{Chemicals}

$\alpha$-Tocopherol, DPPH radical, ABTS and DMPD were purchased commercially from SigmaAldrich GmbH (Sternheim, Germany). Ascorbic acid ( $\geq 99 \%$, Sigma-Aldrich), (-)-epigallocatechin (>97\%, TRC Canada), chlorogenic acid, verbascoside (86.31\%, HWI ANALYTIK GMBH), orientin (>97\%, TRC Canada), caffeic acid ( $\geq 98 \%$, Sigma-Aldrich ), luteolin-7-rutinoside (>97\%, Carbosynth limited), naringin ( $\geq 90 \%$, Sigma-Aldrich), luteolin 7-glucoside (>97\%, TRC Canada), hesperidin ( $\geq$ $98 \%$ J\&K), rutin ( $\geq 94 \%$, Sigma-Aldrich), syringic acid ( $\geq 95 \%$, Sigma-Aldrich), rosmarinic acid ( $\geq 96$ $\%$ Sigma-Aldrich), hyperoside ( $>97 \%$ TRC Canada), apigenin 7-glucoside ( $>97 \%$, EDQM CS), quercitrin $(>97 \%$, TRC Canada), quercetin ( $\geq 95 \%$ Sigma-Aldrich), salicylic acid ( $\geq 98 \%$, SigmaAldrich), naringenin ( $\geq 95 \%$, Sigma-Aldrich), luteolin (95\% Sigma-Aldrich), apigenin ( $>97 \%$, TRC Canada), hispidulin ( $>97 \%$, TRC Canada), isosakuranetin ( $>97 \%$, Phytolab), chrysin ( $\geq 96 \%$, SigmaAldrich), acacetin (>97\%, TRC Canada).

\subsection{Plant Materials}


Ferula orientalis L. samples were gathered from Bingöl province in Turkey, Karlıva district, Kaşıkçı village slopes, at 2030 m altitude (location 39 $24^{\prime} 51^{\prime \prime} \mathrm{N}, 41^{\circ} 00^{\prime} 14^{\prime \prime}$ E, M.Pınar 8971 code) in June 2019. Botanist Assoc. Dr. Süleyman Mesut Pınar identified the plant sample according to the Flora of Turkey [26]. Plant sample was deposited at Van Yuzuncu Y1l University, Faculty of Science, Herbarium of the Biology Department (VANF), Van, Turkey.

\subsection{Preparation of Evaporated Ethanolic Extract (EEFO)}

Both extraction methods were carried out as described previously [27]. For determination of the ethanolic extract of aerial parts of Ferula orientalis L. a 50-g plant sample was cut into small pieces, then, pulverized into a fine powder using a mill and mixed with $500 \mathrm{~mL}$ of ethanol and then evaporated [28]. This process was repeated until the extraction solution turned colorless. The combined extracts were filtered (Whatman paper), and evaporated (Heidolph Hei-VAP HL, Germany). Dry ethanolic extract of Ferula orientalis L. (EEFO) was transferred to an appropriate plastic bottle and kept at -20 ${ }^{\circ} \mathrm{C}$ until used in experiments.

\subsection{Preparation of Lyophilized Ethanolic Extract (WEFO)}

For lyophilized water extraction of shade-dried Ferula orientalis L.,50-g plant samples powdered and mixed with $500 \mathrm{~mL}$ of water, boiled and stirred for $20 \mathrm{~min}$. Then, the extract was filtered and frozen at $-87^{\circ} \mathrm{C}$ in an ultra-low temperature freezer. Frozen extract was lyophilized at $-50{ }^{\circ} \mathrm{C}$ at a pressure of $5 \mathrm{~mm}-\mathrm{Hg}$ in a lyophilizer [29]. Prepared fresh lyophilized ethanolic extract of Ferula orientalis $\mathrm{L}$. (WEFO) was kept in a plastic bottle and stored at $-20{ }^{\circ} \mathrm{C}$ until used in the experiments.

\subsection{Reducing Ability}

The ferric ion reducing ability of EEFO and WEFO was performed according to Oyaizu [30] as given in previously [31]. For this aim, $2.5 \mathrm{~mL}$ of $\mathrm{K}_{3} \mathrm{Fe}(\mathrm{CN})_{6}$ solution $(1 \%)$, which is prepared in phosphate buffer $(0.2 \mathrm{M}, 2.5 \mathrm{~mL}$ and $\mathrm{pH} 6.6)$ was incubated during $30 \mathrm{~min}$. at dark $\left(50^{\circ} \mathrm{C}\right)$. After that, the same volume of TCA $(10 \%)$ was transferred to the reaction medium. Then, an aliquot of $\mathrm{FeCl}_{3}$ $(0.1 \%, 0.5 \mathrm{~mL})$ was added and the absorbance was recorded at $700 \mathrm{~nm}$.

The $\mathrm{Cu}^{2+}$ ion reducing effects of EEFO and WEFO was made according to spectrophotometric assay of Apak et al. [32] as described previously in detail [33]. EEFO and WEFO were prepared at diverse concentrations $(10-30 \mu \mathrm{g} / \mathrm{mL})$ added to $\mathrm{CuCl}_{2}$ solution $(250 \mu \mathrm{L}, 10 \mathrm{mM})$, Then $250 \mu \mathrm{L}$ neocuproine solution, which dissolved in ethanol $(7.5 \mathrm{mM})$ and $250 \mu \mathrm{L}$ of acetate buffer $(1.0 \mathrm{M})$ transferred to the mixture. Finally, after half an hour, the absorbances were recorded at $450 \mathrm{~nm}$.

FRAP reduction ability was determined in accordance with our previous study [34]. Firstly, EEFO and WEFO and standard solutions were transferred to the test tubes, which included several concentrations $(50-150 \mu \mathrm{g} / \mathrm{mL})$. The volumes were supplemented with $0.5 \mathrm{~mL}$ of buffer solution, then, a same volume $(2250 \mu \mathrm{L})$ of $\mathrm{FeCl}_{3}(20 \mathrm{mM})$ and FRAP reactant were transferred to the tubes, respectively. They were vortexed and recorded at $593 \mathrm{~nm}$ after a period $10 \mathrm{~min}$.

\subsection{Metal Chelating Ability}

The metal-binding effect of EEFO and WEFO was performed according to the spectroscopic method of Dinis et al. [35] as described in our previous studies [36,37]. For this process, a solution containing $0.05 \mathrm{~mL}$ of $\mathrm{FeCl}_{2} .4 \mathrm{H}_{2} \mathrm{O}(2 \mathrm{mM})$ and $0.35 \mathrm{~mL}$ of deionized water was transferred to $0.2 \mathrm{~mL}$ of solution containing EEFO and WEFO. Final volume was compilated to $4 \mathrm{~mL}$ with ethanol. Finally, the reaction was started by the addition of $0.2 \mathrm{~mL}$ of ferrous solution $(5 \mathrm{mM})$. The solution was vigorously stirred, vortexed and stood at room temperature. After a short incubation period (10 min), the absorbance was spectrophotometrically recorded at $562 \mathrm{~nm}$.

\subsection{Radical Scavenging Ability}


Anticholinergic, antidiabetic and antioxidant activities of Ferula orientalis

The DPPH scavenging ability of EEFO and WEFO was determined in accordance with the method of Blois [38] as given in previous report [39]. Then, stock solutions $(1.0 \mathrm{mM})$ were transferred to the test tubes in differ concentrations $(25-75 \mu \mathrm{g} / \mu \mathrm{L})$. Finally, total volume was completed to $3 \mathrm{~mL}$ with ethanol, then $1 \mathrm{~mL}$ DPPH radical solution was added to each test tube and the absorbance was measured at $517 \mathrm{~nm}$.

The $\mathrm{ABTS}^{+}$scavenging ability of EEFO and WEFO was realized according to the previous study [40]. Primarily an ABTS solution $(7.0 \mathrm{mM})$ was produced by adding to $\mathrm{K}_{2} \mathrm{~S}_{2} \mathrm{O}_{8}(2.45 \mathrm{nM})$ and the absorbance was set to $0.700 \pm 0.025$ at $734 \mathrm{~nm}$ upon dilution with buffer solution (0.1 M and $\mathrm{pH} 7.4)$. Finally, an aliquot $(1 \mathrm{~mL})$ of ABTS radicals was transferred to diverse concentrations $(10-30 \mu \mathrm{g} / \mathrm{mL})$ of EEFO and WEFO $(10-30 \mu \mathrm{g} / \mathrm{mL})$ and the absorbance was recorded at $734 \mathrm{~nm}$.

\subsection{Anticholinergic Assay}

AChE and BChE inhibitions are used within the scope of anticholinergic studies. The $\mathrm{AChE} / \mathrm{BChE}$ inhibitory effects of EEFO and WEFO were determined in accordance with Ellman's method [41] as given in previous studies [42,43]. AChE and BChE were commercially purchased and obtained from electric eel (Electrophorus electricus) and equine serum, respectively. DTNB and acetylthiocholine iodide/butyrylthiocholine iodide (AChI/BChI) were used as substrates for both cholinergic reactions [44].

\subsection{Antidiabetic Assays}

The inhibition of two digestive enzymes by EEFO and WEFO was studied within the scope of the antidiabetic study. The efficacy of $\alpha$-Glycosidase (from Saccharomyces cerevisiae) inhibition by EEFO and WEFO was performed according to the method of Tao et al. [45] using p-nitrophenyl-Dglucopyranoside ( $p$-NPG) substrate and previously described in detail [47]. The absorbances of samples were spectrophotometrically recorded at $405 \mathrm{~nm}$ [48]. $\alpha$-Amylase activity (from porcine pancreas) was determined according to the Xiao's procedure [1]. Starch was used as substrate and prepared in $80 \mathrm{~mL}$ $\mathrm{NaOH}$ solution $\left(0.4 \mathrm{M}, 30 \mathrm{~min}\right.$, and $\left.80^{\circ} \mathrm{C}\right)$.

\subsection{Determination of Inhibition Parameters}

The $\mathrm{IC}_{50}$ was obtained from the activity $(\%)$ versus plant concentration plots $[49,50]$.

\subsection{Total Phenolic Contents}

Total phenolics in EEFO and WEFO were calculated by the Folin-Ciocalteu method [51] as described in a previous study [52]. The quantity of total phenolics in EEFO and WEFO were calculated from the gallic acid calibration curve. Also, total flavonoids in EEFO and WEFO were determined according to a previous colorimetric method [53]. The standard quercetin curve (0-100 $\mu \mathrm{g})$ was used to determine total flavonoids in EEFO and WEFO. The results are given as $\mu \mathrm{g}$ quercetin equivalents $(\mathrm{QE})$ per g plant extract.

\subsection{Preparation of Samples for LC-HRMS Analysis}

The dried 50-100 mg of the ethanol-water extracts of plants were dissolved in water in a $5 \mathrm{~mL}$ volumetric flask, which was kept in an ultrasonic bath until a clear mixture was occurred. Then, $100 \mu \mathrm{L}$ of dihydrocapsaicin solution, which used as an internal standard, was transferred and diluted to the volume with mobile phase and stirred and heated to get a clear solution. Then, the solution was filtered ( $0.45 \mu \mathrm{m}$ Millipore Millex-HV filter). The concentration of final solution $(1 \mathrm{~mL})$ was added in a capped autosampler vial, from which $2 \mu \mathrm{L}$ of sample was injected to $\mathrm{LC}$ for each run. The prepared samples in the auto sampler were stored at $15^{\circ} \mathrm{C}$ [53-57]. 
Table 1. LC-HRMS parameters of selected compounds.

\begin{tabular}{|c|c|c|c|c|c|c|c|}
\hline Compounds & $m / z$ & $\begin{array}{l}\text { Ionization } \\
\text { mode }\end{array}$ & $\begin{array}{c}\text { Linear } \\
\text { range }\end{array}$ & $\begin{array}{c}\text { Linear regression } \\
\text { equation }\end{array}$ & $\begin{array}{l}\text { LOD/ } \\
\text { LOQ }\end{array}$ & $\mathbf{r}^{2}$ & $\begin{array}{c}\text { Recovery } \\
\%\end{array}$ \\
\hline Ascorbic acid & 175.0248 & Negative & $0.5-10$ & $y=0.00347 x-0.00137$ & $0.39 / 1.29$ & 0.998 & 96.2 \\
\hline (-)-Epigallocatechin & 307.0812 & Positive & $0.3-5$ & $y=0.00317 x+0.000443$ & $0.17 / 0.57$ & 0.994 & 102.2 \\
\hline Chlorogenic acid & 353.0878 & Negative & $0.05-10$ & $y=0.00817 x+0.000163$ & $0.02 / 0.06$ & 0.999 & 96.7 \\
\hline Verbascoside & 623.1981 & Negative & $0.1-10$ & $y=0.00758 x+0.000563$ & $0.03 / 0.1$ & 0.999 & 96.2 \\
\hline Orientin & 447.0933 & Negative & $0.1-10$ & $y=0.00757 x+0.000347$ & $0.01 / 0.03$ & 0.999 & 96.2 \\
\hline Caffeic acid & 179.0350 & Negative & $0.3-10$ & $y=0.0304 x+0.00366$ & $0.08 / 0.27$ & 0.999 & 94.5 \\
\hline Luteolin-7-rutinoside & 593.1512 & Negative & $0.1-10$ & $y=0.00879 x+0.000739$ & $0.01 / 0.03$ & 0.998 & 93.1 \\
\hline Naringin & 579.1719 & Negative & $0.05-10$ & $y=0.00576 x-0.000284$ & $0.01 / 0.03$ & 0.999 & 101.9 \\
\hline Luteolin7-glucoside & 447.0933 & Negative & $0.1-7$ & $y=0.0162 x+0.00226$ & $0.01 / 0.03$ & 0.996 & 96.3 \\
\hline Hesperidin & 609.1825 & Negative & $0.05-10$ & $y=0.00423 x+0.0000138$ & $0.01 / 0.03$ & 0.999 & 96.1 \\
\hline Rutin & 609.1461 & Negative & $0.05-10$ & $y=0.00329 x-0.00005576$ & $0.01 / 0.03$ & 0.999 & 97.0 \\
\hline Syringic acid & 197.0456 & Negative & $0.5-10$ & $y=0.0000831 x+0.000024$ & $0.1 / 0.3$ & 0.999 & 97.3 \\
\hline Rosmarinic acid & 359.0772 & Negative & $0.05-10$ & $y=0.00717 x-0.0003067$ & $0.01 / 0.03$ & 0.999 & 99.9 \\
\hline Hyperoside & 463.0882 & Negative & $0.05-10$ & $y=0.0072 x-0.00003096$ & $0.01 / 0.03$ & 0.999 & 96.6 \\
\hline Apigenin7-glucoside & 431.0984 & Negative & $0.3-7$ & $y=0.0246 x+0.00306$ & $0.01 / 0.03$ & 0.996 & 96.1 \\
\hline Quercitrin & 447.0933 & Negative & $0.05-10$ & $\mathrm{y}=0.0179+0.0003331$ & $0.01 / 0.03$ & 0.999 & 97.0 \\
\hline Quercetin & 301.0354 & Negative & $0.1-10$ & $y=0.0509 x+0.00467$ & $0.01 / 0.03$ & 0.997 & 96.4 \\
\hline Salicylic acid & 137.0244 & Negative & $0.3-10$ & $y=0.0361 x+0.00245$ & $0.01 / 0.03$ & 0.998 & 92.9 \\
\hline Naringenin & 271.0612 & Negative & $0.1-10$ & $y=0.0281 x+0.00182$ & $0.01 / 0.03$ & 0.999 & 86.7 \\
\hline Luteolin & 285.0405 & Negative & $0.1-10$ & $y=0.117 x+0.00848$ & $0.01 / 0.03$ & 0.998 & 96.9 \\
\hline Apigenin & 269.0456 & Negative & $0.3-10$ & $y=0.104 x+0.0199$ & $0.01 / 0.03$ & 0.999 & 81.5 \\
\hline Hispidulin & 301.0707 & Positive & $0.05-10$ & $y=0.02614 x+0.0003114$ & $0.01 / 0.03$ & 0.999 & 98.4 \\
\hline Isosakuranetin & 285.0769 & Negative & $0.05-10$ & $y=0.0235 x+0.000561$ & $0.01 / 0.03$ & 0.999 & 96.6 \\
\hline Chrysin & 253.0506 & Negative & $0.05-7$ & $y=0.0964 x-0.0002622$ & $0.01 / 0.03$ & 0.999 & 87.9 \\
\hline Acacetin & 283.0612 & Negative & $0.05-7$ & $y=0.046 x+0.0001875$ & $0.01 / 0.03$ & 0.999 & 87.5 \\
\hline
\end{tabular}

\subsection{Instruments and Chromatographic Conditions of LC-HRMS}

LC-HRMS experiments were achieved on a Thermo ORBITRAP Q-EXACTIVE mass spectrometery (Bremen Germany) equipped with a Troyasil (Istanbul, Turkey) C18 column (150 x 3 $\mathrm{mm}$ i.d., $3 \mu \mathrm{m}$ particle size). The mobile phases A and B were composed of $1 \%$ formic acid-water and $1 \%$ formic acid-methanol, respectively. The gradient program of which was $0-1.00 \mathrm{~min} 50 \% \mathrm{~A}$ and $50 \%$ $\mathrm{B}, 1.01-6.00 \mathrm{~min} 100 \% \mathrm{~B}$, and finally $6.01-10 \mathrm{~min} 50 \% \mathrm{~A}$ and $50 \% \mathrm{~B}$. The flow rate of the mobile phase was $0.35 \mathrm{~mL} / \mathrm{min}$, and the column temperature was set to $22^{\circ} \mathrm{C}$. Environmental conditions were set as temperature $22.0 \pm 5.0{ }^{\circ} \mathrm{C}$ and relative humidity $(50 \pm 15) \%$ rh $[58,59]$.

\subsection{Optimization of HPLC Methods and LC-HRMS Procedure}

The best mobile phase was performed to be an acidified methanol and water gradient in HPLC method. This mobile phase was also found to be suitable for ionization abundance and separation of compounds. The best ionization of small and relatively polar compounds was obtained by ESI source. The ions between $\mathrm{m} / \mathrm{z}$ 85-1500 were scanned in high-resolution mode of instrument [11,54-61]. Identification of compounds was performed by comparison of retention time of standard compounds (in the range of purity 95-99\% see section chemicals) and HRMS data of Bezmialem Vakif University, Drug Application and Research Center Library (ILMER). Dihydrocapsaicin (purity 95\%) was used as an internal standard for LC-HRMS measurements in order to reduce the repeatability problem caused by external effects, such as ionization repeatability, in mass spectrometry measurements. The detailed mass parameters of each target compound are given in Table 1. 
Anticholinergic, antidiabetic and antioxidant activities of Ferula orientalis

\subsection{Method Validation of LC-HRMS Method}

Validation of LC-HRMS method was carried out using analytical standards of corresponding compounds (see section 2.1) with using the ions in Table 1 and dihydrocapsaicin was used as an internal standard. Validation parameters are selected as selectivity, linearity, recovery, repeatability, intermediate precision, limit of detection (LOD) and limit of quantification (LOQ). LODs of the method for individual compounds were determined according to the following equation: $\mathrm{LOD}$ or $\mathrm{LOQ}=\kappa \mathrm{SDa} / \mathrm{b}$, where 3 for LOQ and $\kappa=3$ for LOD, SDa represents the standard deviation of the intercept, and $b$ represents the slope. Detailed validation procedure and uncertainty assessment methodology of the applied method was reported in our previous paper [58,59]. Linear range, linear regression equation, $\mathrm{r}^{2}$, Recovery and LOD and LOQ data are summarized in Table 1.

\section{Results and Discussion}

Antioxidant and antiradical properties of EEFO and WEFO were carried out in diverse concentrations using different bioanalytical methods such as its $\left(\mathrm{Fe}^{2+}\right)$ chelating activity, $\mathrm{Fe}^{3+}$ reducing ability, $\mathrm{Fe}^{3+}-\mathrm{TPTZ}$ reduction capacity, $\mathrm{Cu}^{2+}$ reduction capability, and ABTS and DPPH radicals scavenging activities. For comparison of antioxidant effects, putative $\alpha$-tocopherol, BHT and ascorbic acid were used as positive controls. It was also found that the antioxidant activities of both extracts are similar or close to standard antioxidants. Also, it was shown that the antioxidant activity of EEFO and WEFO enhanced with increasing concentrations (10-30 $\mu \mathrm{g} / \mathrm{mL})$. In some cases, the antioxidant ability of EEFO and WEFO was observed to be higher than standard antioxidants at the same concentration. It is well known that the reduction ability is one of the most significant factors in its total antioxidant effectiveness [62]. The antioxidant efficiency can take place through different mechanisms. For example, in a system in which oxidation is accelerated by transition metals, the reduction of antioxidant property of a compound is not significant for antioxidant properties. However, even if the antioxidant only consists of the metal chelating ability, it will stop or slow down the oxidation in such a system. Additionally, electron-withdrawing capacity reflects the reducing ability of a compound [63]. Antioxidants may be in the form of stabilizing oxidants in reductant and redox reactions. The reduction capacity can be recorded by diverse bioanalytical methods. In the presence of reducing compounds, the reduction of ferric complexes $\left(\mathrm{Fe}\left[(\mathrm{CN})_{6}\right]^{3+}\right)$ to the ferrous form $\left(\mathrm{Fe}\left[(\mathrm{CN})_{6}\right]^{2+}\right)$ can readily occur. The addition of $\mathrm{Fe}^{3+}$ to the reduced product by addition of EEFO and WEFO leads to the formation of $\mathrm{Fe}_{4}\left[\mathrm{Fe}(\mathrm{CN})_{6}\right]$, a complex in the Prussian blue color with sharp absorbance at $700 \mathrm{~nm}$ [64].

The increased absorbance shows the increased reduction capacity. As seen in Table 2, EEFO and WEFO exhibited potent $\mathrm{Fe}^{3+}$ reducing ability and these diversities were statistically found as considerably important ( $\mathrm{p}<0.01$ ). The reducing capacity of EEFO, WEFO, BHT, $\alpha$-tocopherol, and ascorbic acid increased constantly when the concentration of sample was increased. $\mathrm{Fe}^{3+}$ reducing capacity of EEFO, WEFO and standards exposed the following order: Ascorbic acid $\left(\lambda_{700}: 1.520 \pm 0.028\right.$, $\left.\mathrm{r}^{2}: 0.9970\right)>\operatorname{BHT}\left(\lambda_{700}: 1.269 \pm 0.005, \mathrm{r}^{2}: 0.9880\right)>\alpha$-tocopherol $\left(\lambda_{700}: 0.990 \pm 0.007, \mathrm{r}^{2}: 0.9942\right)>$ EEFO $\left(\lambda_{700}: 0.845 \pm 0.026, \mathrm{r}^{2}: 0.9390\right)$ and WEFO $\left(\lambda_{700}: 0.645 \pm 0.011, \mathrm{r}^{2}: 0.9996\right)$ at $20 \mu \mathrm{g} / \mathrm{mL}$. The results showed that EEFO and WEFO had marked and powerful $\mathrm{Fe}^{3+}$ reducing effects. 
Kızıltaş et.al., Rec. Nat. Prod. (2021) 15:6 513-528
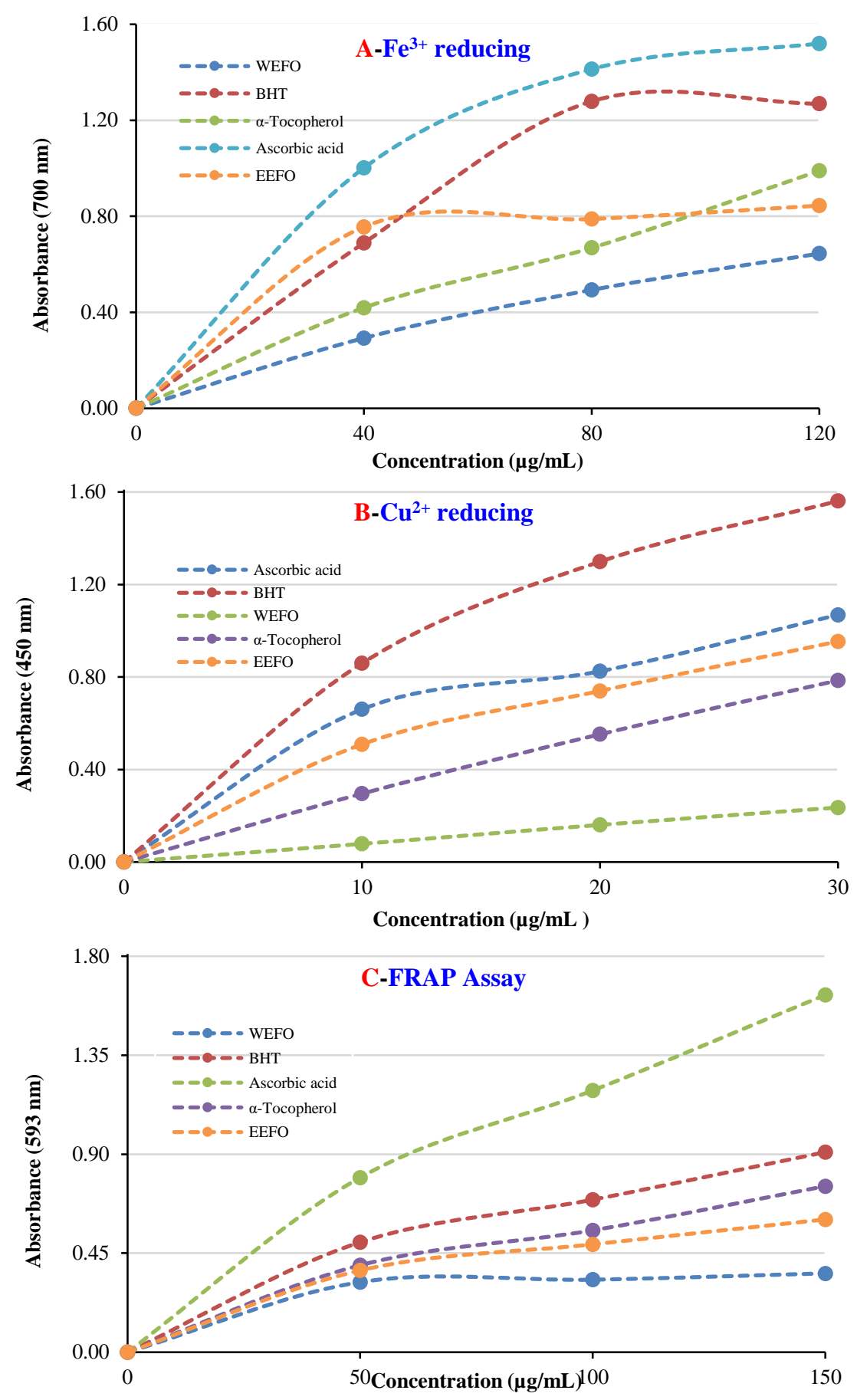

Figure 1. Reducing ability of different concentrations of EEFO, WEFO and standard antioxidants. A. $\mathrm{Fe}^{3+}$ reducing power. B. $\mathrm{Cu}^{2+}$ reducing power. C. $\mathrm{Fe}^{3+}$-TPTZ reducing power [EEFO: Evaporated ethanolic extract of aerial parts Ferula orientalis L. WEFO: Lyophilized water extract of aerial parts of Ferula orientalis L., BHT: butylated hydroxytoluene] 


\section{Anticholinergic, antidiabetic and antioxidant activities of Ferula orientalis}

Another putative and commonly used method is the reduction ability of $\mathrm{Fe}^{3+}$-TPTZ. It was observed that there was a relationship between the three reduction methods applied to define the reduction capacities of EEFO and WEFO in the studies conducted. Also, it was found that EEFO and WEFO and standard antioxidants showed similar activities in all reduction methods. As can be seen in Table 2, EEFO and WEFO had the effective $\mathrm{Fe}^{3+}\left(\mathrm{CN}^{-}\right)_{6}, \mathrm{Cu}^{2+}-\mathrm{Cu}^{+}$, and $\mathrm{Fe}^{3+}-\mathrm{TPTZ}$ reducing abilities, when compared with ascorbic acid, BHT, and $\alpha$-tocopherol. The results clearly showed that reducing power of EEFO and WEFO and standards decreased in the following order (Table 1): Ascorbic acid $\left(\lambda_{700}: 1.624 \pm 0.015, \mathrm{r}^{2}: 0.9930\right)>\operatorname{BHT}\left(\lambda_{700}: 0.909 \pm 0.006, \mathrm{r}^{2}: 0.9874\right)>\alpha$-tocopherol $\left(\lambda_{700}: 0.755 \pm 0.075\right.$, $\left.r^{2}: 0.9867\right)>$ EEFO $\left(\lambda_{700}: 0.604 \pm 0.004, r^{2}: 0.9843\right)$ and WEFO $\left(\lambda_{700}: 0.358 \pm 0.016, r^{2}: 0.9373\right)$. In this assay, ferric ions $\left(\mathrm{Fe}^{3+}\right)$ are reduced to ferrous ions $\left(\mathrm{Fe}^{2+}\right)$ in the presence of an antioxidant molecule or extract at the acidic medium (pH 3.6) [65].

Table 2. The reducing power of the EEFO and WEFO and standards antioxidants by $\mathrm{Fe}^{3+}-\mathrm{Fe}^{2+}(120 \mu \mathrm{g} / \mathrm{mL})$, $\mathrm{Cu}^{2+}-\mathrm{Cu}^{+}(30 \mu \mathrm{g} / \mathrm{mL})$ and $\mathrm{Fe}^{3+}-\mathrm{TPTZ}(150 \mu \mathrm{g} / \mathrm{mL})$ reducing methods (EEFO: Evaporated ethanolic extract of aerial parts Ferula orientalis L. WEFO: Lyophilized water extract of aerial parts of Ferula orientalis L.)

\begin{tabular}{|c|c|c|c|c|c|c|}
\hline \multirow{2}{*}{ Antioxidants } & \multicolumn{2}{|c|}{$\mathrm{Fe}^{3+}-\mathrm{Fe}^{2+}$ reducing } & \multicolumn{2}{|c|}{$\mathrm{Cu}^{2+}-\mathrm{Cu}^{+}$reducing } & \multicolumn{2}{|c|}{$\mathrm{Fe}^{3+}$-TPTZ reducing } \\
\hline & $\lambda 700$ & $\mathbf{r}^{2}$ & $\lambda_{450}$ & $\mathbf{r}^{2}$ & $\lambda 593$ & $\mathbf{r}^{2}$ \\
\hline$\alpha$-Tocopherol & $0.990 \pm 0.007$ & 0.9942 & $0.785 \pm 0.061$ & 0.9986 & $0.755 \pm 0.075$ & 0.9867 \\
\hline Ascorbic acid & $1.520 \pm 0.028$ & 0.9970 & $1.069 \pm 0.007$ & 0.9722 & $1.624 \pm 0,015$ & 0.9930 \\
\hline BHT & $1.269 \pm 0.005$ & 0.9880 & $1.561 \pm 0.089$ & 0.9978 & $0.909 \pm 0.006$ & 0.9874 \\
\hline EEFO & $0.845 \pm 0.026$ & 0.9390 & $0.954 \pm 0.017$ & 0.9928 & $0.604 \pm 0.004$ & 0.9843 \\
\hline WEFO & $0.645 \pm 0.011$ & 0.9996 & $0.236 \pm 0.020$ & 0.9998 & $0.358 \pm 0.016$ & 0.9373 \\
\hline
\end{tabular}

Copper is one of putative metals, which can occur in nature in a directly usable metallic form. It is a crucial metal for some endogenous antioxidant enzymes like cytochrome c oxidase [66]. This chromogenic redox reaction measures antioxidants with thiols like non-protein thiols and glutathione. The cupric ions $\left(\mathrm{Cu}^{2+}\right)$ reducing ability of $20 \mu \mathrm{g} / \mathrm{mL}$ of EEFO, WEFO and standards was shown in Table 2. A positive correlation was observed between the $\mathrm{Cu}^{2+}$ reducing ability and different concentrations of the EEFO and WEFO. It was found that $\mathrm{Cu}^{2+}$ reducing ability of EEFO and WEFO was occurred in a concentration-dependent manner. $\mathrm{Cu}^{2+}$-reducing ability of EEFO and WEFO and standards at the same concentration $(30 \mu \mathrm{g} / \mathrm{mL})$ demonstrated the following order: BHT $\left(\lambda_{700}: 1.561 \pm 0.089, \mathrm{r}^{2}: 0.9978\right)$ $>$ ascorbic acid $\left(\lambda_{700}: 1.069 \pm 0.007, \mathrm{r}^{2}: 0.9722\right)>\alpha$-tocopherol $\left(\lambda_{700}: 0.785 \pm 0.061, \mathrm{r}^{2}: 0.9986\right)>$ EEFO $\left(\lambda_{700}: 0.954 \pm 0.017, \mathrm{r}^{2}: 0.9928\right)$ and WEFO $\left(\lambda_{700}: 0.236 \pm 0.020, \mathrm{r}^{2}: 0.9998\right)$.

Table 3. The half maximum concentration $\left(\mathrm{IC}_{50}, \mu \mathrm{g} / \mathrm{mL}\right)$ of EEFO, WEFO and standards for the DPPH, DMPD, ABTS radicals scavenging activities (EEFO: Evaporated ethanolic extract of aerial parts Ferula orientalis L. WEFO: Lyophilized water extract of aerial parts of Ferula orientalis L.)

\begin{tabular}{|c|c|c|c|c|c|c|}
\hline \multirow{2}{*}{ Compounds } & \multicolumn{2}{|c|}{ DPPH• scavenging } & \multicolumn{2}{|c|}{ ABTS $^{\bullet+}$ scavenging } & \multicolumn{2}{|c|}{ Metal chelating } \\
\hline & $\mathrm{IC}_{50} *$ & $\mathbf{r}^{2}$ & $\mathrm{IC}_{50} *$ & $\mathbf{r}^{2}$ & $\mathrm{IC}_{50} *$ & $\mathbf{r}^{2}$ \\
\hline$\alpha$-Tocopherol & 30.1 & 0.9578 & 8.1 & 0.9606 & 33.0 & 0.9006 \\
\hline Ascorbic acid & 17.3 & 0.9509 & 7.5 & 0.9519 & 99.0 & 0.9985 \\
\hline BHT & 38.5 & 0.9858 & 5.8 & 0.9539 & 14.7 & 0.9647 \\
\hline EEFO & 346.5 & 0.8507 & 90.9 & 0.9901 & 4.39 & 0.9334 \\
\hline WEFO & 86.6 & 0.9916 & 17.3 & 0.9968 & $-*$ & $-*$ \\
\hline
\end{tabular}

*They were not determined.

The iron-chelating ability is very significant due to ionic species like ferrous ion $\left(\mathrm{Fe}^{2+}\right)$ facilitating the production of free ROS in the organism [67]. This binding assay is a significant antioxidant method used for prevention or delaying of oxidation processes catalyzed by metal ions, however excessive metal ions can cause cell damage. Among the metal ions, ferrous ions $\left(\mathrm{Fe}^{2+}\right)$ are the most significant prooxidant ions. It is a significant lipid oxidizing metal due to it has high activity in transition metals. $\mathrm{Fe}^{2+}$ ions are more reactive than $\mathrm{Fe}^{3+}$ ions [68]. These reactions can also occur $\mathrm{OH}$ 
radicals, which are more reactive than the end-peroxides. Metal-binding effects of EEFO and WEFO was evaluated using two distinct metal chelator agents including ferrozine reagent [69]. When the $\mathrm{IC}_{50}$ values of the binding effect of EEFO and WEFO in the study were compared with the $\mathrm{IC}_{50}$ of the EEFO, WEFO and standard antioxidants was found as effective metal chelator with $\mathrm{IC}_{50}: 4.39 \mu \mathrm{g} / \mathrm{mL}\left(\mathrm{r}^{2}\right.$ : 0.9334, Table 3) using ferrozine reagent, however, this value could not be determined for WEFO. Also, relatively higher $\mathrm{IC}_{50}$ values were found for $\alpha$-tocopherol $\left(\mathrm{IC}_{50}: 33.0 \mu \mathrm{g} / \mathrm{mL}, \mathrm{r}^{2}: 0.9006\right)$, ascorbic acid ( $\left.\mathrm{IC}_{50}: 99.0 \mu \mathrm{g} / \mathrm{mL}, \mathrm{r}^{2}: 0.9985\right)$, and BHT (IC $\left.{ }_{50}: 14.7 \mu \mathrm{g} / \mathrm{mL}, \mathrm{r}^{2}: 0.9647\right)$.

The radical scavenging is very significant in terms of damage to the organism by free radicals and ROS in living organisms. Recently, many distinct methods have been developed for the removal of ROS and free radicals. Thus, they reduce the quality of the food and pharmaceutical products [70]. The spectrophotometric methods based on the radical scavenging are frequently used for determination of antioxidant abilities of substances, beverages, food, and herbal extracts. In addition, $\mathrm{ABTS}^{+}$and $\mathrm{DPPH}$. scavenging methods are fast, simple, selective and repeatable procedures. So, they are widely used to define the radical elimination abilities. It is easy to use the violet $\mathrm{DPPH}$ - and green-blue ABTS ${ }^{+}$ chromogens, which have high sensitivity [71]. As seen in Table 3, within the scope of DPPH free radical scavenging studies, $\mathrm{IC}_{50}$ values for EEFO and WEFO had less effective $\mathrm{DPPH}$. scavenging and were found to be $346.5 \mu \mathrm{g} / \mathrm{mL}\left(\mathrm{r}^{2}: 0.8507\right)$ and $86.6 \mu \mathrm{g} / \mathrm{mL}$ for ascorbic acid $\left(\mathrm{r}^{2}: 0.9916\right)$. As with DPPH radical scavenging ability, $\mathrm{ABTS}^{+}$scavenging ability is extensively used for determination of radical scavenging activities of beverages, extracts and substances [69]. ABTS ${ }^{+}$is more reactive radical than DPPH radical. As shown in Table 3, it is observed that EEFO and WEFO had effective ABTS radical removing effects. The $\mathrm{IC}_{50}$ value of $\mathrm{ABTS}^{+}$scavenging activity for EEFO and WEFO was calculated as $90.9 \mu \mathrm{g} / \mathrm{mL}\left(\mathrm{r}^{2}: 0.9901\right)$ and $17.3 \mu \mathrm{g} / \mathrm{mL}\left(\mathrm{r}^{2}: 0.9968\right)$, respectively. Also, this value was counted 5.8 $\mu \mathrm{g} / \mathrm{mL}$ for BHT $\left(\mathrm{r}^{2}: 0.9539\right), 8.1 \mu \mathrm{g} / \mathrm{mL}$ for $\alpha$-tocopherol $\left(\mathrm{r}^{2}: 0.9606\right)$ and $7.5 \mu \mathrm{g} / \mathrm{mL}$ for ascorbic acid $\left(r^{2}: 0.9606\right)$. The results clearly demonstrated the EEFO and WEFO have effective, but lower ABTS ${ }^{+}$ scavenging ability than that of all standard antioxidants.
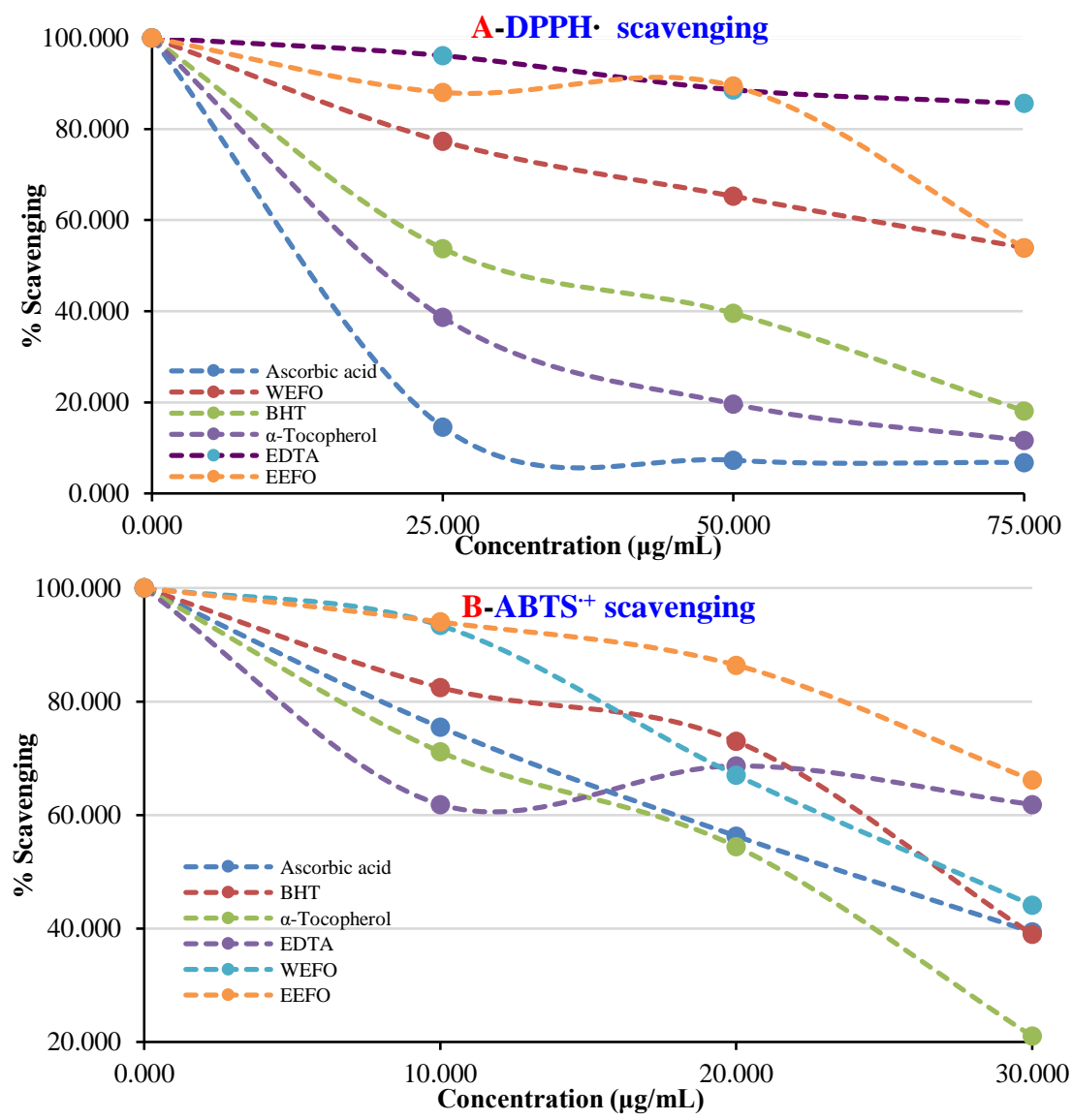
Anticholinergic, antidiabetic and antioxidant activities of Ferula orientalis

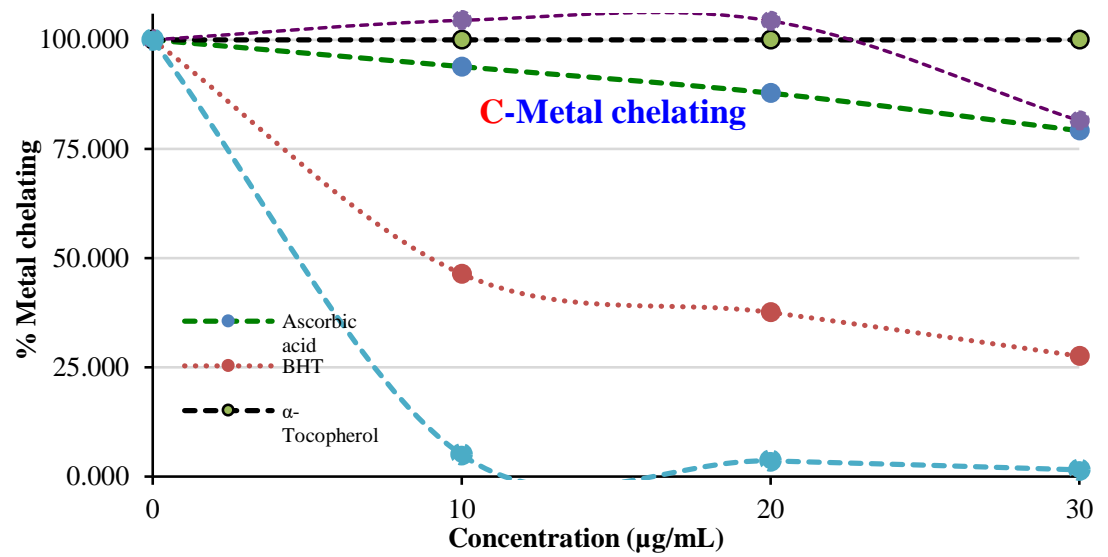

Figure 2. A) DPPH radical scavenging activity. B) ABTS radical scavenging activity. C)Metal chelating activity [EEFO: Evaporated ethanolic extract of aerial parts Ferula orientalis L. WEFO: Lyophilized water extract of aerial parts of Ferula orientalis L., BHT: butylated hydroxytoluene]

Acetylcholinesterase (AChE) is another important metabolic enzyme and had been associated in some neurodegenerative diseases such as AD and Parkinson diseases [72]. The AChE inhibition had a positive effect on the long-term progression of $\mathrm{AD}$. In this context, there are many published studies on the inhibition effects of compounds and crude extracts. One such compound is galantamine and used to treat mild $\mathrm{AD}$ to moderate $\mathrm{AD}$ and firstly isolated from Galanthus woronowii [73]. Also, MEFO effectively inhibited AChE with $\mathrm{IC}_{50}$ values of $1.946 \mu \mathrm{g} / \mathrm{mL}\left(\mathrm{r}^{2}: 0.9752\right)$ and for AChE. On the other hand, tacrine was used as positive control for AChE inhibition, and had $\mathrm{K}_{\mathrm{i}}$ value of $0.124 \mu \mathrm{M}\left(\mathrm{r}^{2}: 0.9804\right)$ against $\mathrm{AChE}$, which is the primary cholinesterase at mainly neuromuscular junctions and in chemical synapses in the body [74]. However, it was observed that WEFO had not any effects against the used metabolic enzymes.

Similarly, EEFO had effective inhibition against $\alpha$-glycosidase with $\mathrm{IC}_{50}$ values of $0.815 \mu \mathrm{g} / \mathrm{mL}$ $\left(r^{2}: 0.9525\right)$. Tacrine was used as positive control for both cholinergic enzyme inhibition, and had $\mathrm{K}_{\mathrm{i}}$ value of $0.101 \mu \mathrm{M}\left(\mathrm{r}^{2}: 0.9698\right)$ against AChE. Aside from these inhibition properties, EEFO had demonstrated marked inhibition effect against $\alpha$-amylase, which is an extracellular enzyme and hydrolyzes glycogen and starch to glucose units, with $\mathrm{IC}_{50}$ values of $0.675 \mu \mathrm{g} / \mathrm{mL}\left(\mathrm{r}^{2}: 0.9706\right)$.

Until recently, diabetes has remained one of the fastest growing, serious and costly health problems in the world. Its complete cure and effective drugs for treatment are still not available [75]. Recently, herbal extracts and their compounds have received great attention as antioxidants and potential inhibitors of key and metabolic enzymes, used in clinical conditions. For example, $\alpha$-glycosidase and $\alpha$ amylase as essential digestive enzymes in carbohydrate metabolism has been considered a key target for reducing postprandial hyperglycemia in diabetic patients.

In this context, it has been reported that biologically active compounds like acarbose, voglibose and miglitol reduce postprandial hyperglycemia by inhibiting enzymes that carry out carbohydrate digestion, thereby delaying or partially inhibiting glucose absorption [76]. A recent research has been conducted directly towards the discovery of amylase inhibitors of naturally effective ingredients and extracts with potential use as therapeutic agents for the treatment of diabetes and prevention of diseases. Human saliva $\alpha$-amylase is the most plentiful digestive enzyme in human saliva that hydrolyzes polysaccharides such as starch to oligosaccharides [75]. EEFO had $\mathrm{IC}_{50}$ value of $0.68 \mu \mathrm{g} / \mathrm{mL}\left(\mathrm{r}^{2}: 0.9706\right)$ toward $\alpha$-glycosidase and $0.82 \mu \mathrm{g} / \mathrm{mL}$ against $\alpha$-amylase enzyme $\left(\mathrm{r}^{2}: 0.9525\right)$ (Table 3$)$. The results show that EEFO as a crude extract exhibited efficient $\alpha$-glycosidase and $\alpha$-amylase inhibition effect than that of acarbose, which had $\mathrm{IC}_{50}$ of $10.00 \mu \mathrm{M}$ for $\alpha$-amylase, $22.80 \mu \mathrm{M}$ for a-glucosidase. The results clearly showed that EEFO had more effective inhibition than that of acarbose, which was a starch blocker [77].

Total phenolic compound in EEFO and WEFO was determined using the Folin-Ciocalteu reagent. Gallic acid, which is easily obtained in large amounts by acid or alkaline hydrolysis of tannin, was used for a standard graph $\left(\mathrm{r}^{2}: 0.9840\right)$. Plants, vegetables and fruits are important phenolic 
compounds sources of human diet. Accordingly, the consumption of foods including polyphenols had a great importance for their natural antioxidants [68]. The quantity of phenolics in EEFO and WEFO was determined using the equation taken from standard gallic acid graph as gallic acid equivalents (GAE/mg extract). On the other hand, for determination of total flavonoids content of EEFO and WEFO, a standard quercetin chart was used. The quantity of flavonoids was determined with the equation of standard flavonoid graph. It was shown that 4.9 and $6.7 \mu \mathrm{g}$ of QE flavonoids were found in $1 \mathrm{mg}$ of EEFO and WEFO, respectively.

Table 4. The quantity ( $\mathrm{mg} / \mathrm{kg}$ extract) of phenolic antioxidant compounds in EEFO and WEFO determined by LC-HRMS chromatograms.

\begin{tabular}{|c|c|c|c|}
\hline Compounds & WEFO & EEFO & $\mathrm{U}(\%)$ \\
\hline Ascorbic acid & 139.41 & $<\mathrm{LOD}$ & 3.94 \\
\hline (-)-Epigallocatechin & $<\mathrm{LOD}$ & 0.04 & 3.09 \\
\hline Chlorogenic acid & 7409.23 & 0.73 & 3.58 \\
\hline Verbascoside & 4.62 & $<$ LOD & 2.93 \\
\hline Orientin & $<\mathrm{LOD}$ & $<$ LOD & 3.67 \\
\hline Caffeic acid & 149.17 & 0.02 & 3.74 \\
\hline Luteolin-7-rutinoside & $<\mathrm{LOD}$ & $<\mathrm{LOD}$ & 3.06 \\
\hline Naringin & 3.61 & $<$ LOD & 4.20 \\
\hline Luteolin 7-glucoside & $<\mathrm{LOD}$ & $<$ LOD & 4.14 \\
\hline Rutin & 15.74 & $<\mathrm{LOD}$ & 3.07 \\
\hline Rosmarinic acid & 71.30 & 0.09 & 3.77 \\
\hline Hyperoside & 1864.20 & 0.18 & 3.46 \\
\hline Apigenin 7-glucoside & $<\mathrm{LOD}$ & $<$ LOD & 3.59 \\
\hline Quercitrin & 33.73 & $<\mathrm{LOD}$ & 3.78 \\
\hline Quercetin & 4.79 & 0.01 & 2.95 \\
\hline Salicylic acid & 4.79 & $<$ LOD & 1.89 \\
\hline Naringenin & $<\mathrm{LOD}$ & $<$ LOD & 4.20 \\
\hline Luteolin & 0.65 & $<$ LOD & 3.42 \\
\hline Apigenin & $<\mathrm{LOD}$ & 0.01 & 2.87 \\
\hline Hispidulin & $<\mathrm{LOD}$ & $<\mathrm{LOD}$ & 3.41 \\
\hline Isosakuranetin & $<\mathrm{LOD}$ & $<$ LOD & 3.98 \\
\hline Chrysin & 5.09 & $<$ LOD & 3.24 \\
\hline Acacetin & 3.25 & 0.03 & 3.98 \\
\hline Fumaric acid & $<\mathrm{LOD}$ & 0.16 & 2.88 \\
\hline
\end{tabular}

Also, the standard chromatogram for phenolic compounds by LC-HRMS ( $\mathrm{mg} / \mathrm{mL})$ is given in Figure 1. According to LC-HRMS analysis, the main phenolic compounds identified in WEFO are chlorogenic acid $(7409.23 \mathrm{mg} / \mathrm{kg})$, hyperoside $(1864.20 \mathrm{mg} / \mathrm{kg})$ and caffeic acid $(149.17 \mathrm{mg} / \mathrm{kg})$. On the other hand, chlorogenic acid $(0.73 \mathrm{mg} / \mathrm{kg})$, hyperoside $(0.18 \mathrm{mg} / \mathrm{kg})$ and (-)-epigallocatechin $(0.04$ $\mathrm{mg} / \mathrm{kg}$ ) are the most abundant phenolics in $1 \mathrm{mg}$ of EEFP (Table 4). Phenolic compounds, in other words polyphenols, are predominantly of plant origin. They give color to the plants. The plants protect themselves using polyphenols against many external influences. The antioxidant property of polyphenols is well established and well known [78]. Phenolic compounds have biological functions such as free radical scavenger and metal chelator. In plants, the antioxidant effects of phenolics are mainly due to redox effects. For this reason, hydrogen donors, reducing agents, singlet oxygen inhibitors and metal chelates act as builders [54].

\section{Conclusion}

The determination of the bioactivity and screening of phytochemical of EEFO and WEFO had great importance. Both extracts were evaluated for their bioactivities contain antioxidant activities and some 


\section{Anticholinergic, antidiabetic and antioxidant activities of Ferula orientalis}

metabolic enzymes inhibitory properties associated with several global diseases. Generally, the high action of the EEFO was in proportional to its phenolic content when compared to WEFO. Indeed, many studies have also found that a positive correlation between total phenolic and flavonoid contents of plant extracts and their biological efficiencies. In addition, when the LC-HRMS results are evaluated, it is clearly seen that the main phenolic compounds responsible for the antioxidant and other biological activities of both extracts are chlorogenic acid, hyperoside, and caffeic acid. Ethanol was observed as effective solvent for the extraction of phenolics with effective antioxidant activity and inhibition of $\alpha$ glycosidase, AChE and $\alpha$-amylase enzymes. Nowadays, enzyme inhibition to control overactive enzyme activities has become a key target in the treatment or management of many chronic diseases, especially $\mathrm{AD}$, cancer and diabetes.

\section{Acknowledgments}

S. Alwasel would like to extend his sincere appreciation to the Researchers Supporting Project (RSP-2021/59), King Saud University, Saudi Arabia.

\section{Supporting Information}

Supporting information accompanies this paper on http://www.acgpubs.org/journal/records-ofnatural-products

$\begin{array}{ll}\text { ORCID } & \\ \text { Hatice K1ziltaş } & : \underline{0000-0002-0833-3358} \\ \text { Ahmet C. Gören } & : \underline{0000-0002-5470-130 X} \\ \text { Zeynebe Bingöl } & : \underline{0000-0003-3373-779 X} \\ \text { Saleh H. Alwasel } & : \underline{0000-0002-0626-2306} \\ \text { İlhami Gülçin } & : \underline{0000-0001-5993-1668}\end{array}$

\section{References}

[1] I. Gulcin, A. C. Gören, P. Taslimi, S. H .Alwasel, O. Kilic and E. Bursal (2020). Anticholinergic, antidiabetic and antioxidant activities of Anatolian pennyroyal (Mentha pulegium)-Analysis of its polyphenol contents by LC-MS/MS, Biocat. Agric. Biotechnol. 23, 101441.

[2] T.Aysu and M. M. Kucuk (2013). Liquefaction of giant fennel (Ferula orientalis L.) in supercriticalorganic solvents: Effects of liquefaction parameters on product yields and character, $J$. Supercrit. Fluids 83, 104-123.

[3] P. Polycarpou (2012). Ethanol production from Ferula communis, Biomass Bioenerg. 36, $289-292$.

[4] E. Koksal and I. Gulcin (2008). Antioxidant activity of cauliflower (Brassica oleracea L.), Turk. J. Agric. For. 32, 65-78.

[5] A. Baran, E. Karakılıç, O. Faiz and F. Özen (2020). Synthesis of chalcone-containing zinc and cobalt metallophthalocyanines; investigation of their photochemical, DPPH radical scavenging and metal chelating characters, Org. Commun.13, 65-78.

[6] L. S. Lai, S. T. Chou and W. W. Chao (2001). Studies on the antioxidative activities of Hsian-tsao (Mesona procumbens Hems L.) leaf gum, J. Agric. Food Chem. 49, 963-968.

[7] M. Elmastas, İ. Türkekul, L. Öztürk, I. Gulcin, Ö. Işıldak and H. Y. Aboul-Enein (2006). The antioxidant activity of two wild edible mushrooms (Morchella vulgaris and Morchella esculanta), Comb. Chem. High Throughput Screen. 9(6), 443-448

[8] M. Valko, C. J .Rhodes, J. Moncol, M. Izakovic and M. Mazur (2006). Free radicals, metals and antioxidants in oxidative stress-induced cancer, Chem. Biol. Interact. 160, 1-40.

[9] H. T. Balaydın, I. Gulcin, A. Menzek, S. Göksu and E. Şahin (2010). Synthesis and antioxidant properties of diphenylmethane derivative bromophenols including a natural product, J. Enzyme Inhib. Med. Chem. 25(5), 685-695.

[10] I. Gulcin, F. Topal, S. B .Oztürk Sarikaya, E. Bursal, A .C. Gören and M. Bilsel (2011). Polyphenol contents and antioxidant properties of medlar (Mespilus germanica L.), Rec. Nat. Prod. 5(3), 158-175. 
[11] M.Topal (2020). Secondary metabolites of ethanol extracts of Pinus sylvestris cones from eastern Anatolia and their antioxidant, cholinesterase and alpha-glucosidase activities, Rec. Nat. Prod. 14(2), 129-138.

[12] M. Skerget, P. Kotnik, M. Hadolin, A. R. Hras, M. Simonic and Z. Knez (2005). Phenols, proanthocyanidins, flavones and flavonols in some plant materials and their antioxidant activities, Food Chem. 89, 191-198.

[13] E. M. Katrucha, J. Lopes, M. Paim, J. C. Santos, D. A. Siebert, G. A. Micke, L. Vitali, M. D. Alberton and A. Tenfen (2020). Phenolic profile by HPLC-ESI-MS/MS and enzymatic inhibitory effect of Bryophyllum delagoense, Nat. Prod. Res.11, 1-4. doi: 10.1080/14786419.2020.1729147

[14] E. Bursal, P. Taslimi, A. Gören and I. Gulcin (2020). Assessments of anticholinergic, antidiabetic, antioxidant activities and phenolic content of Stachys annua, Biocat. Agric. Biotechnol. 28, 101711.

[15] T. Artunç, A. Menzek, P. Taslimi, I. Gulcin, C. Kazaz and E. Şahin (2020). Synthesis and antioxidant activities of phenol derivatives from 1,6-bis(dimethoxyphenyl)hexane-1,6-dione, Bioorg. Chem. 100, 103884

[16] A. Cipriani, A. L. de Sousa, A. Tenfen, D. A. Siebert, A. L. de Gasper, L.Vitali, G. A. Micke and M.D. Alberton (2020). Phenolic compounds of Eugenia involucrata (Myrtaceae) extracts and associated antioxidant and inhibitory effects on acetylcholinesterase and $\alpha$-glucosidase, Nat. Prod. Res. 1-4. doi: $10.1080 / 14786419.2020 .1855640$

[17] K. Çetin Çakmak and I. Gulcin (2019). Anticholinergic and antioxidant activities of usnic acid-An activity-structure insight, Toxicol. Rep. 6, 1273-1280.

[18] I. Gulcin, B.Trofimov, R. Kaya, P. Taslimi, L. Sobenina, E. Schmidt, O. Petrova, S. Malysheva, N. Gusarova, V. Farzaliyev, A. Sujayev, S. Alwaseland and C. T. Supuran (2020). Synthesis of nitrogen, phosphorus, selenium and sulfur-containing heterocyclic compounds-determination of their carbonic anhydrase, acetylcholinesterase, butyrylcholinesterase and $\alpha$-glucosidase inhibition properties, Bioorg. Chem. 103, 104171.

[19] H. Zaidi, S. Ouchemoukh, N. Amessis-Ouchemoukh, N. Debbache, R. Pacheco, M. L. Serralheiro and M. E. Araujo (2019). Biological properties of phenolic compound extracts in selected Algerian honeysThe inhibition of acetylcholinesterase and $\alpha$-glucosidase activities, Eur. J. Integ. Med. 25, 77-84.

[20] H. Genç Bilgiçli, D. Ergön, P. Taslimi, B. Tüzün, İ. Akyazı Kuru, M. Zenginand and I. Gulcin (2020). Novel propanolamine derivatives attached to 2-metoxifenol moiety: Synthesis, characterization, biological properties, and molecular docking studies, Bioorg. Chem. 101, 103969.

[21] I. Gulcin, A. Scozzafava, C. T. Supuran, H. Akıncioğlu, Z. Koksal, F. Turkan and S. Alwasel (2016). The effect of caffeic acid phenethyl ester (CAPE) metabolic enzymes including acetylcholinesterase, butyrylcholinesterase, glutathione s-transferase, lactoperoxidase and carbonic anhydrase isoenzymes I, II, IX and XII, J. Enzyme Inhib. Med. Chem. 31(6), 1095-1101.

[22] I. Gulcin, P. Taslimi, A. Aygün, N. Sadeghian, E. Bastem, Ö. İ. Küfrevioğlu, F. Turkan and F. Şen (2018). Antidiabetic and antiparasitic potentials: Inhibition effects of some natural antioxidant compounds on $\alpha$ glycosidase, $\alpha$-amylase and human glutathione S-transferase enzymes, Int. J. Biol. Macromol. 119, 741746.

[23] P. Taslimi, H. E. Aslan, Y. Demir, N. Öztaşkın, A. Maraş, I. Gulcin, Ş. Beydemir and Ş. Göksu (2018). Diarilmethanon, bromophenols and diarilmetan compounds: discovery of potent aldose reductase, $\alpha$ amylase and $\alpha$-glycosidase inhibitors as new therapeutic approach in diabetes and functional hyperglycemia, Int. J. Biol. Macromol. 119, 857-863.

[24] M. Zengin, I. Gulcin, P. Taslimi, A. Kestane, E. Güçlü, A. Ögütlü, O. Karabay and İ. Gülçin (2018). Novel thymol bearing oxypropanolamine derivatives as potent some metabolic enzyme inhibitors-their antidiabetic, anticholinergic and antibacterial potentials, Bioorg. Chem. 81, 119-126.

[25] B. Özgeriş, S. Göksu, L. Köse Polat, I. Gulcin, R. E. Salmas, S. Durdagi, F. Tümer and C. T. Supuran (2016). Acetylcholinesterase and carbonic anhydrase inhibitory properties of novel urea and sulfamide derivatives incorporating dopaminergic 2-aminotetralin scaffolds, Bioorg. Med. Chem. 24(10), 23182329.

[26] H.Peşmen (1972). Ferula L. In: Davis PH, ed. Flora of Turkey and the East Aegean Islands, Vol. 4. Edinburgh: Edinburgh University Press, 440-453.

[27] I. Gulcin (2005). The antioxidant and radical scavenging activities of black pepper (Piper nigrum) seeds, Int. J. Food Sci. Nutr. 56(7), 491-499.

[28] H. Tohma, I. Gulcin, E. Bursal, A.C. Gören, S. H. Alwasel and E. Köksal (2017). Antioxidant activity and phenolic compounds of ginger (Zingiber officinale Rosc.) determined by HPLC-MS/MS, J. Food Measure. Charac. 11(2), 556-566. 


\section{Anticholinergic, antidiabetic and antioxidant activities of Ferula orientalis}

[29] I. Gulcin, E. Bursal, H. M. Şehitoğlu, M. Bilsel and A. C. Gören (2010). Polyphenol contents and antioxidant activity of lyophilized aqueous extract of propolis from Erzurum, Turkey, Food Chem. Toxicol. 48 (8-9), 2227-2238.

[30] M. Oyaizu (1986). Studies on products of browning reaction prepared from glucoseamine. Jpn. J. Nutr. 44, 307-314.

[31] I. Gulcin, Ş. Beydemir, İ. G. Şat and Ö. İ. Küfrevioğlu (2005). Evaluation of antioxidant activity of cornelian cherry (Cornus mas L.), Acta Aliment. Hung. 34(2), 193-202.

[32] R. Apak, K. Güçlü, M. Özyürek, S. E. Karademir and E. Erça (2006). The cupric ion reducing antioxidant capacity and polyphenolic content of some herbal teas, Int. J. Food Sci. Nutr. 57, 292-304.

[33] I. Gulcin and A. Daştan (2007). Synthesis of dimeric phenol derivatives and determination of in vitro antioxidant and radical scavenging activities, J. Enzyme Inhib. Med. Chem. 22(6), 685-695.

[34] Y. Çetinkaya, H. Göçer, A. Menzek and I. Gulcin (2012). Synthesis and antioxidant properties of (3,4dihydroxyphenyl)(2,3,4-trihydroxyphenyl)methanone and its derivatives, Arch. Pharm. 345(4), 323-334.

[35] T. C. P. Dinis, V. M .C. Maderia and L. M. Almeida (1994). Action of phenolic derivates (acetaminophen, salicylate and 5-aminosalicylate) as inhibitors of membrane lipid peroxidation and as peroxyl radical scavengers, Arch. Biochem. Biophys. 315, 161-169.

[36] E. Koksal, E. Bursal, I. Gulcin, M. Korkmaz, C. Çağlayan, A. C. Goren and S. H. Alwasel (2017). Antioxidant activity and polyphenol content of Turkish thyme (Thymus vulgaris) monitored by LCMS/MS, Int. J. Food Prop. 20(3), 514-525.

[37] Z. Huyut, S. Beydemir and I. Gulcin (2017). Antioxidant and antiradical properties of some flavonoids and phenolic compounds, Biochem. Res. Int. 7616791.

[38] M.S. Blois (1958) Antioxidant determinations by the use of a stable free radical, Nature 26, 1199-1200.

[39] M. Rezai, Ç. Bayrak, P. Taslimi, I. Gulcin and A. Menzek (2018). The first synthesis, antioxidant and anticholinergic activities of 1-(4,5-dihydroxybenzyl)pyrrolidin-2-one derivative bromophenols including natural products, Turk. J. Chem.42(3), 808-825.

[40] P. Taslimi and I. Gulcin(2018). Antioxidant and anticholinergic properties of olivetol, J. Food Biochem.42(3), e12516.

[41] G. L. Ellman, K. D. Courtney, V. Andres and R. M. Featherston (1961). A new and rapid colorimetric determination of acetylcholinesterase activity, Biochem. Pharmacol. 7, 88-95.

[42] N. Eruygur, M. Ataş, M. Tekin, P. Taslimi, U. M. Koçyiğit and I. Gulcin(2019). In vitro antioxidant, antimicrobial, anticholinesterase and antidiabetic activities of Turkish endemic Achillea cucullata (Asteraceae) from ethanol extract, South Afr. J. Bot. 120, 141-145.

[43] L. Polat Köse, I. Gulcin, A. C. Gören, J. Namiesnik, A. L. Martinez-Ayala and S. Gorinstein, (2015). LCMS/MS analysis, antioxidant and anticholinergic properties of galanga (Alpinia officinarum Hance) rhizomes, Ind. Crops Prod. 74, 712-721.

[44] N. Lolak, S. Akocak, C. Turkes, P. Taslimi, M. Işık, Ş. Beydemir, I. Gulcin and M. Durgun (2020). Synthesis, characterization, inhibition effects, and molecular docking studies as acetylcholinesterase, $\alpha$ glycosidase, and carbonic anhydrase inhibitors of novel benzenesulfonamides incorporating 1,3,5triazine structural motifs, Bioorg. Chem. 100, 103897.

[45] Y. Tao, Y. F. Zhang, Y. Y .Cheng and Y. Wang (2013). Rapid screening and identification of alphaglucosidase inhibitors from mulberry leaves using enzyme-immobilized magnetic beads coupled with HPLC/MS and NMR, Biomed. Chromatogr. 27, 148-155.

[46] P. Taslimi, H. Akıncioğlu and I. Gulcin (2017). Synephrine and phenylephrine act as $\alpha$-amylase, $\alpha$ glycosidase, acetylcholinesterase, butyrylcholinesterase and carbonic anhydrase enzymes inhibitors, $J$. Biochem. Mol. Toxicol. 31(11), e21973.

[47] Y. Demir, P. Taslimi, U. M. Koçyiğit, M. Akkuş, M. S. Özaslan, H. E. Duran, Y. Budak, B. Tüzün, M. B. Gürdere, M. Ceylan, S. Taysi, I. Gulcin and Ş. Beydemir (2020). Determination of inhibition profile of pyrazolyl-thiazole derivatives on aldose reductase, $\alpha$-glycosidase enzymes and molecular docking studies, Arch. Pharm. 353(12), e2000118.

[48] Z. Xiao, R. Storms and A. Tsang (2006). A quantitative starch-iodine method for measuring alphaamylase and glucoamylase activities, Anal. Biochem. 351, 146-148.

[49] H. Kızıltaş, Z. Bingöl, A.C. Gören, L. Polat Köse, L. Durmaz, F. Topal, S.H. Alwasel and İ. Gulçin (2021). LC-HRMS profiling, antidiabetic, anticholinergic and anti-oxidant activities of aerial parts of kınkor (Ferulago stelleta), Molecules 26, 2469.

[50] C. Caglayan, P. Taslimi, C. Türk, I. Gulcin, F. M. Kandemir, Y. Demir and S. Beydemir (2020). Inhibition effects of some pesticides and heavy metals on carbonic anhydrase enzyme activity purified from horse mackerel (Trachurus trachurus) gill tissues, Environ. Sci. Poll. Res. 27, 10607-10616.

[51] I. Gulcin (2012). Antioxidant activity of food constituents: an overview, Arch. Toxicol. 86(3), 345-391 
[52] O. Folin and V. Ciocalteu (1927). On tyrosine and tryptophane determinations in proteins, J. Biol. Chem.73, 627-650.

[53] I. Gulcin (2020). Antioxidants and antioxidant methods-An updated overview, Arch. Toxicol. 94, 651715.

[54] P. Kalın, I. Gulcin and A. C. Gören (2015). Antioxidant activity and polyphenol content of cranberries (Vaccinium macrocarpon), Rec. Nat. Prod. 9, 496-502.

[54] H. O. Hamad, M. H. Alma, I. Gulcin, M. A. Y1lmaz and E. Karaoğul (2017). Evaluation of phenolic contents and bioactivity of root and nutgall extracts from Iraqian Quercus infectoria Olivier, Rec. Nat. Prod. 11, 205-210.

[55] H. Han, H. Yılmaz and I. Gulcin (2018). Antioxidant activity of flaxseed (Linum usitatissimum L.) and analysis of its polyphenol contents by LC-MS/MS, Rec. Nat. Prod. 14, 340-354.

[56] A. C. Goren, G. Bilsel and M. Bilsel (2007). Rapid and simultaneous determination of 25-OH-vitamin D 2 and D 3 in human serum by LC/MS/MS: Validation and uncertainty assessment, J. Chem.Metrol. 1, $1-9$.

[57] F. Akbas, A. Ozaydin, E. Polat and I. Onaran (2020). Lucilia sericata larval secretions stimulatingwound healing effects on rat dermal fibroblast cells, Rec. Nat. Prod. 12, 397-402.

[58] Z. Özer, S. Çarıkçı, H. Yılmaz, T. Kılıç, T. Dirmenci and A. C. Gören (2020). Determination of secondary metabolites of Origanum vulgare subsp. hirtum and $O$. vulgare subsp. vulgare by LC-MS/MS, J. Chem. Metrol. 14, 25-34.

[59] D. Dincel, H. Olgan, Z. Canbaloğlu, S. Yalcin, A. Erkuçuk, G. Tırıs and A. C. Gören (2020). Determination of dihydrocapsaicin adulteration in dietary supplements using LC-MS/MS, J. Chem. Metrol. 14, 77-82.

[60] E. Bursal, A. Aras, Ö. Kılıç, P. Taslimi, A. C. Gören and I. Gulcin (2019). Phytochemical content, antioxidant activity and enzyme inhibition effect of Salvia eriophora Boiss. \& Kotschy against acetylcholinesterase, $\alpha$-amylase, butyrylcholinesterase and $\alpha$-glycosidase enzymes, J. Food Biochem .43(3), e12776.

[61] N. Öztaskin, R. Kaya, A. Maraş, E. Sahin, I. Gulcin and S. Göksu (2019). Synthesis and characterization of novel bromophenols: Determination of their anticholinergic, antidiabetic and antioxidant activities, Bioorg. Chem .87, 91-102.

[62] I. Gulcin, A. Z. Tel, A. C. Gören, P. Taslimi and S. Alwasel (2019). Sage (Salvia pilifera): Determination its polyphenol contents, anticholinergic, antidiabetic and antioxidant activities, J. Food Measure. Charac. 13(3), 2062-2074

[63] D. D. Miller (1996). Minerals. In "Food Chemistry”, O.R. Fennema (Ed), pp: 617-649. Marcel Dekker, New York.

[64] I. Gulcin, R. Kaya, A. C. Gören, H. Akıncıŏglu, M. Topal, Z. Bingöl, K. Çetin Çakmak, S. B. Ozturk Sarikaya, L. Durmaz and S. Alwasel (2019). Anticholinergic, antidiabetic and antioxidant activities of Cinnamon (Cinnamomum verum) bark extracts: Polyphenol contents analysis by LC-MS/MS, Int. J. Food Prop.22, 1511-1526.

[65] F. Turkan, M. N. Atalar, A. Aras, I. Gulcin and E. Bursal (2020). ICP-MS and HPLC analyses, enzyme inhibition and antioxidant potential of Achillea schischkinii Sosn, Bioorg. Chem. 94, 103333.

[66] P. Taslimi, E. Koksal, A. C. Gören, E. Bursal, A. Aras, O. Kılıç, S. Alwasel and I. Gulcin(2020). AntiAlzheimer, antidiabetic and antioxidant potential of Satureja cuneifolia and analysis of its phenolic contents by LC-MS/MS, Arab. J. Chem. 13(3), 4528-4537.

[67] L. Polat Köse, Z. Bingöl, R. Kaya, A. C. Gören, H. Akincioğlu, L. Durmaz, E. Koksal, S. Alwasel and I. Gulcin (2020). Anticholinergic and antioxidant activities of avocado (Folium perseae) leaves phytochemical content by LC-MS/MS analysis, Int. J. Food Prop. 23, 878-893.

[68] H. Tohma, E. Köksal, Ö. Kılıç, Y. Alan, M. A. I. Yılmaz, I. Gulcin, E. Bursal and S. H. Alwasel (2016). RP-HPLC/MS/MS analysis of the phenolic compounds, antioxidant and antimicrobial activities of Salvia L. species, Antioxidants 5, 38, doi: 10.3390/antiox5040038

[69] D. Ozmen Ozgun, C. Yamali, H. İ. Gül, P. Taslimi, I. Gulcin, T. Yanik and C. T. Supuran (2016). Inhibitory effects of isatin Mannichbases on carbonic anhydrases, acetylcholinesterase and butyrylcholinesterase, $J$. Enzyme Inhib. Med. Chem. 31(6), 1498-1501.

[70] C. G. Ballard, N. H. Greig, A .L. Guillozet-Bongaarts, A. Enz and S. Darvesh (2005). Cholinesterases: Roles in the brain during health and disease, Curr. Alzheimer Res. 2(3), 307-318.

[71] H. Akıncioglu and I. Gulcin(2020). Potent acetylcholinesterase inhibitors: potential drugs for Alzheimer's disease, Mini Rev. Med. Chem. 20(8), 703-715.

[72] S. R. M. Ibrahim, G. A. Mohamed, M. F. Zayed and S. A. (2017).Ross 8-Hydroxyirilone 5-methyl ether and 8 -hydroxyirilone, new antioxidant and $\alpha$-amylase inhibitors isoflavonoids from Iris germanica rhizomes, Bioorg. Chem. 70, 192-198. 
Anticholinergic, antidiabetic and antioxidant activities of Ferula orientalis

[73] G. Zengin, A. Uysal, A. Diuzheva, E. Gunes, J. Jeko, Z. Cziakyand C. M. N. Picot-Allain and M. F. Mahomoodally (2018). Characterization of phytochemical components of Ferula halophileextracts using HPLC-MS/MS and their pharmacological potentials: amulti-functional insight, J. Pharm. Biomed. Anal. 160, 374-382

[74] A. Karimov, A. Orujova, P. Taslimi, N. Sadeghian, B. Mammadov, H. S. Karaman, V. Farzaliyev, A., Sujayev, R. Taş, S. Alwasel and I. Gulcin (2020). Novel functionally substituted esters based on sodium diethyldithiocarbamate derivatives: synthesis, characterization, biological activity and molecular docking studies, Bioorg. Chem. 99, 103762.

[75] K. Pedrood, M. Sherefati, P. Taslimi, M. Mohammadi-Khanaposhtani, M. S. Asgari, S. Hosseini, H. Rastegar, B. Larijani, M. Mahdavi, P. Taslimi, Y. Erden, S.Günay and I. Gulçin (2021). Design, synthesis, characterization, enzymatic inhibition evaluations, and docking study of novel quinazolinone derivatives, Int. J. Biol. Macromol. 170, 1-12.

[76] S. Dasgin, Y. Gok, D. Barut Celepci, P. Taslimi, M. İzmirli, A. Aktaş and I. Gulçin (2021).Synthesis, characterization, crystal structure and bioactivity properties of the benzimidazole-functionalized PEPPSI type of Pd(II)NHC complexes, J. Mol. Struct. 1228, 129442.

[77] S. Hashmi, S. Khan, Z. Shafiq, P. Taslimi, M. Ishaq, N. Sadeghian, S. H. Karaman, N. Akhtar, M. Islam, A. Asari, H. Mohamad and İ. Gulçin (2021). Probing 4-(diethylamino)-salicylaldehyde-based thiosemicarbazones as multi-target directed ligands against cholinesterases, carbonic anhydrases and $\alpha$ glycosidase enzymes, Bioorg. Chem. 107, 104554.

[78] E. Bursal and I. Gulcin(2011). Polyphenol contents and in vitro antioxidant activities of lyophilized aqueous extract of kiwifruit (Actinidia deliciosa), Food Res. Int. 44, 1482-1489.

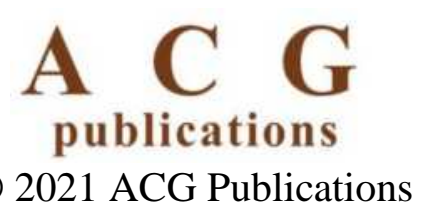

